\title{
Cyanobacteria and Cyanotoxin in the Billings Reservoir (São Paulo, SP, Brazil)
}

\author{
Viviane Moschini-Carlos ${ }^{1, *}$, Stella Bortoli ${ }^{3}$, Ernani Pinto ${ }^{3}$, Paula Yuri Nishimura ${ }^{2}$, Leandro \\ Gomes de Freitas ${ }^{1}$, Marcelo L. M. Pompêo ${ }^{2}$, and Felipe Dörr ${ }^{3}$
}

${ }^{1}$ São Paulo State University-UNESP, Department of Environmental Engineering. 3 de Março Avenue n. 511, PO Box: 18087-180, Sorocaba, São Paulo State, Brazil.

${ }^{2}$ University of São Paulo, Institute of Biociências, Department of Ecology, Rua do Matão, Trav. 14, no 321, PO Box 05508-900, São Paulo-SP, Brazil

${ }^{3}$ University of São Paulo, Laboratory of Toxin and Algae Natural Products, School Pharmaceutical Sciences, Prof. Lineu Prestes Avenue, 580, PO Box 05508-900, São Paulo-SP, Brazil.

* Corresponding author: viviane@ sorocaba.unesp.br

Received: 19/12/08

Accepted: 7/9/09

\begin{abstract}
Cyanobacteria and Cyanotoxin in the Billings Reservoir (São Paulo, SP, Brazil)

The Billings Complex and the Guarapiranga System are important strategic reservoirs for the city of São Paulo and surrounding areas because the water is used, among other things, for the public water supply. They produce 19,000 liters of water per second and supply water to 5.4 million people. Crude water is transferred from the Taquacetuba branch of the Billings Complex to the Guarapiranga Reservoir to regulate the water level of the reservoir. The objective of this study was to evaluate the water quality in the Taquacetuba branch, focusing on cyanobacteria and cyanotoxins. Surface water samples were collected in February (summer) and July (winter) of 2007. Analyses were conducted of physical, chemical, and biological variables of the water, cyanobacteria richness and density, and the presence of cyanotoxins. The water was classified as eutrophic-hypereutrophic. Cyanobacteria blooms were observed in both collection periods. The cyanobacteria bloom was most significant in July, reflecting lower water transparency and higher levels of total solids, suspended organic matter, chlorophyll-a, and cyanobacteria density in the surface water. Low richness and elevated dominance of the cyanobacteria were found in both periods. Cylin-

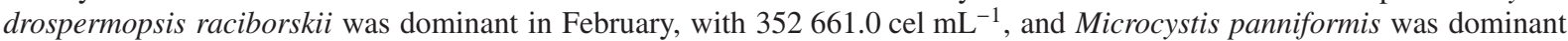

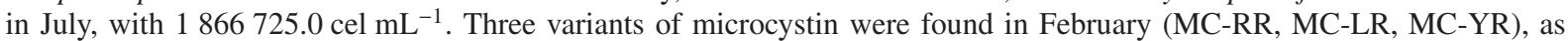
well as saxitoxin. The same variants of microcystin were found in July, but no saxitoxin was detected. Anatoxin-a and cylindropermopsin were not detected in either period. These findings are of great concern because the water in the Taquacetuba branch, which is transferred into the Guarapiranga Reservoir, is not treated nor managed. It is recommended that monitoring be intensified and more effective measures be taken by the responsible agencies to prevent the process of eutrophication and the consequent development of the cyanobacteria and their toxins.
\end{abstract}

Key words: Reservoirs, eutrophication, cyanobacteria, cyanotoxins.

\section{RESUMEN}

\section{Cianobacterias y Cianotoxinas en el Embalse Billings (São Paulo, Brasil)}

El Complejo Billings y el Sistema Guarapiranga son embalses estratégicos importantes para la ciudad de São Paulo (Brasil) y áreas circundantes porque, entre otras cosas, el agua es utilizada para el abastecimiento público. Este sistema produce 19 mil litros de agua por segundo, que es suministrado a 5.4 millones de personas. El agua bruta es transferida por el afluente Taquacetuba desde el Complejo Billings hacia el Embalse Guarapiranga, para regular el nivel de agua del embalse. El objetivo de este estudio fue evaluar la calidad del agua en el tramo del Taquacetuba, teniendo como foco las cianobacterias y cianotoxinas. El muestreo de agua bruta superficial fue realizado en febrero (verano) y julio (invierno 2007). Fueron analizadas variables físicas, químicas y biológicas, cianobacteria, riqueza, densidad y la presencia de cianotoxinas. El tramo fue clasificado como eutrófico-hipereutrófico. Las cianobacterias fueron observadas en ambos periodos de colecta. El crecimiento más 
significativo de algas fue observado en julio, reflejando baja transparencia del agua y niveles más altos en el agua superficial de sólidos totales, materia orgánica, clorofila-a y densidad de cianobacterias en el agua superficial. Una baja riqueza y un elevado dominio de cianobacteria fueron encontrados en ambos periodos. Cylindrospermopsis raciborskii fue dominante en

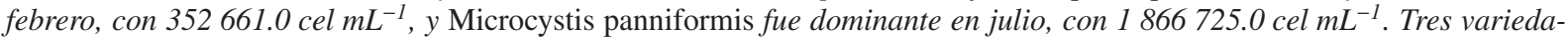
des de microcistina fueron encontradas en febrero (MC-RR, MC-LR, MC-YR), así como saxitoxina. Las mismas variedades de microcistina fueron encontradas en julio, pero ninguna saxitoxina fue observada. Anatoxina-a y cylindropermopsina no fueron observadas en ningún período. Estas conclusiones son preocupantes porque el agua del tramo del Taquacetuba, que es transferida al Embalse Guarapiranga, no es tratada o manejada. Se recomienda intensificar el monitoreo y medidas más eficaces deben ser tomadas por parte de las agencias responsables para prevenir el proceso de eutrofización y el desarrollo consiguiente de cianobacterias y sus toxinas.

Palabras clave: Embalses, eutrofización, cianobacterias, cianotoxinas.

\section{INTRODUCTION}

Cyanobacteria blooms in reservoirs, resulting from the accelerated process of eutrophication, causes the water to have an unpleasant appearance, an increase in turbidity, and it changes the flavor and smell of the water. Some of the main effects due to cyanobacteria blooms comprise a decrease in water transparency, heavy fluctuation of oxygen levels and the release of toxins (Vasconcelos, 2006). Nowadays, cyanobacteria blooms and its toxins are the main problem related to the treatment of public supply water, which can lead to serious public health problems.

In Brazil, the number of cases of cyanobacteria blooms in reservoirs designated for public supply is increasing each year (Andrade, 2005; Azevedo \& Vasconcelos, 2006; Chellappa \& Costa, 2003; Komarek et al., 2002; Sant'Anna \& Azevedo, 2000; Tucci \& Sant'anna, 2003; Yunes et al., 2003). The most severe case of intoxication due to cyanobacterial toxin occurred in 1996 in Caruaru, Pernambuco State, when around 60 people died following treatment hemodialysis sessions done with not well-treated water from a reservoir which had shown cyanobacterial dominance in the previous years (Azevedo et al., 1994).

Considering that urban reservoirs used for water supply in Brazil have been subjected to frequent cyanobacteria blooms due to several variables, such as ecological, physiological, and environmental, research in this area must be encouraged (Calijuri et al., 2006). Therefore, the aim of this study was to evaluate the water quality in the Taquacetuba branch of the Billings Reservoir, focusing on the cyanobacteria and cyanotoxins.

The Billings Reservoir (Fig. 1) is located west of the city of São Paulo at $23^{\circ} 47^{\prime} \mathrm{S}, 46^{\circ} 40^{\prime} \mathrm{W}$, an altitude of $746 \mathrm{~m}$ a.s.l. and its watershed covers an area of $560 \mathrm{~km}^{2}$. Its uses include leisure, fisheries, flow control, domestic and industrial wastewater reception, power generation, and water supply. The reservoir's limnological features changed substantially since 1940 , when part of the polluted water from the Tietê River (São Paulo city) started to flow into the Billings Reservoir, aiming to increase the water flow and consequently, the electric power generation. This operation, along with the disorganized occupation of the watershed, contributed to increase the eutrophication and consequently, the cyanobacterial blooms (Beyruth \& Pereira, 2002; Carvalho et al., 2007; Souza et al., 1998).

Due to its peculiar shape, the Billings Reservoir is divided into eight units called branches. The Taquacetuba branch has a particular use. In August of 2000, the Basic Sanitation Company of the State of São Paulo (SABESP) began to operate a system of transporting crude water from the Taquacetuba branch to the Guarapiranga Reservoir, with a license for $2.0 \mathrm{~m}^{3} \mathrm{~s}^{-1}$. Currently it operates at a volume of 3.0 to $4.0 \mathrm{~m}^{3} \mathrm{~s}^{-1}$, contributing $29 \%$ of the total water produced in the Guarapiranga Reservoir, which supplies water to southeastern São Paulo at a rate of 1.2 billion L day ${ }^{-1}$ (Whately \& Cunha, 2006). 


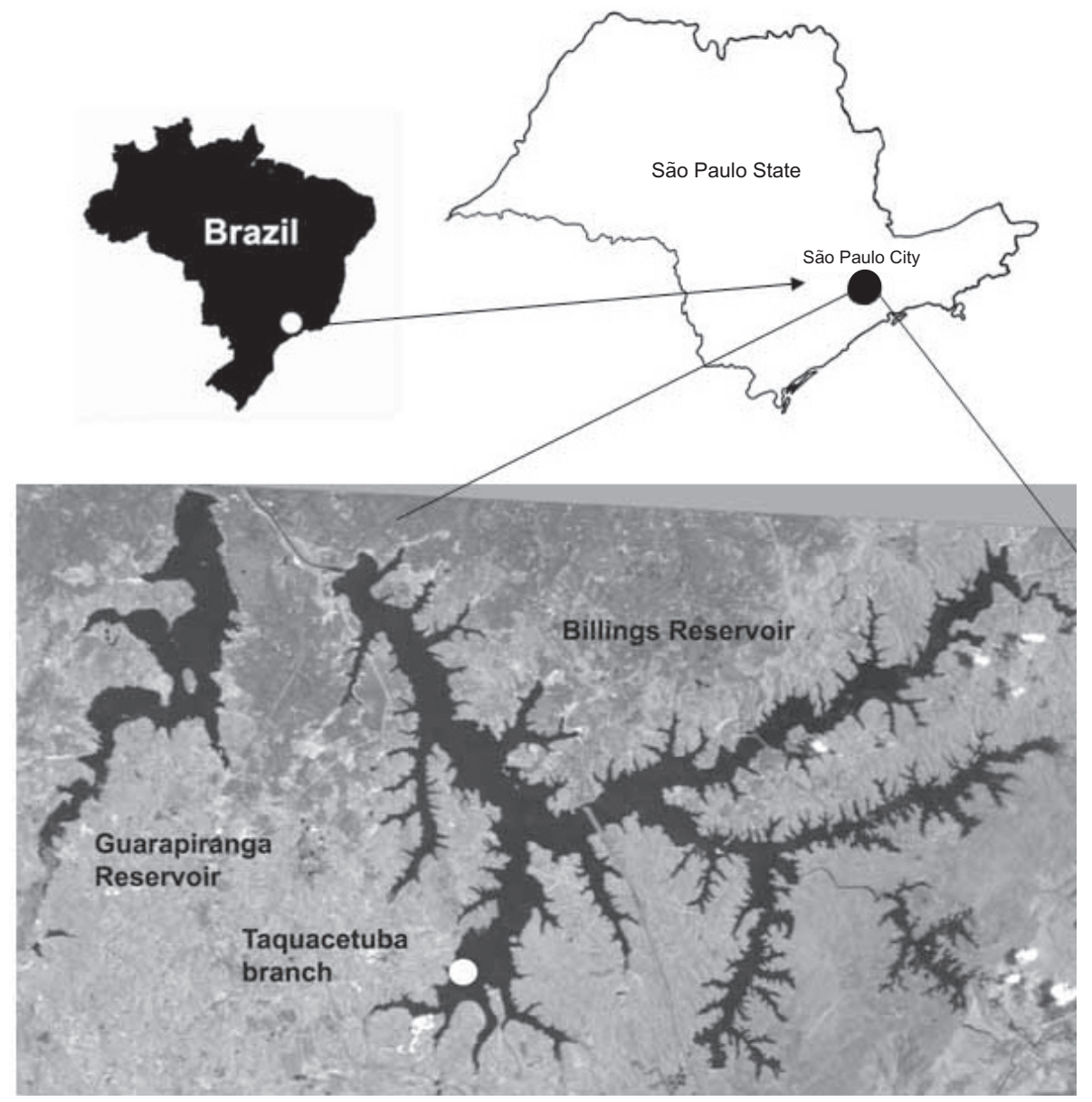

Figure 1. Location of the Billings Reservoir watershed (Taquacetuba branch), State of São Paulo, Brazil. Localización del Embalse de Billings (rama de Taquacetuba), São Paulo, Brasil.

Therefore, the study of the Taquacetuba branch's water quality along with the cyanobacteria community and its toxins, will contribute to understand the actual state of degradation of the water that is transferred into the Billings-Guarapiranga system, which are important strategic reservoirs for the São Paulo city and its surrounding areas, as they produce $19000 \mathrm{~L} \mathrm{~s}^{-1}$ of water to supply 5.4 million people.

\section{METHODOLOGY}

Surface water samples were collected in $\mathrm{Fe}$ bruary (summer) and July (winter) of 2007. Analyses of dissolved oxygen, total and dis- solved nutrients, suspended matter, total solids, chlorophylls $a, b$, and $c$, and phaeopigments (Table 1) were performed. Water transparency was also determined using a Secchi disk, as well as water temperature, electrical conductivity (values corrected to $25^{\circ} \mathrm{C}$ ), and $\mathrm{pH}$ with YSI multiparameter sensor, model 63/100 FT.

Classification of the trophic state of the bodies of water was carried out according to the Trophic State Index (TSI) (Carlson, 1977), modified by Toledo et al. (1983), as follows: oligotrophic TSI $<44$; mesotrophic $44<$ TSI $<54$; eutrophic $54<$ TSI $<74$; hypertrophic TSI $>74$.

Species composition was analyzed using a JENAVAL/ZEISS binocular microscope. Counting was carried out using the sedimentation method 
Table 1. Variables analyzed and their respective detection limits (when applicable), unit, method, and reference. Variables analizadas y sus límites de detección respectivos (cuando aplicable), unidad, método, y referencia.

\begin{tabular}{|c|c|c|c|c|}
\hline Variable & $\begin{array}{l}\text { Detection limit } \\
\text { of the method }\end{array}$ & Unit & Method & Reference \\
\hline \multicolumn{5}{|l|}{$\begin{array}{l}\text { Total, organic, } \\
\text { and inorganic }\end{array}$} \\
\hline suspended matter (TSM, OSM, ISM) & & $\mathrm{mg} \cdot \mathrm{L}^{-1}$ & Gravimetric & Wetzel \& Likens (1991) \\
\hline Total solids (TS) & & $\mathrm{mg} \cdot \mathrm{L}^{-1}$ & Gravimetric & \\
\hline Total nitrogen (TN) & $<5.0$ & $\mu \mathrm{g} \cdot \mathrm{L}^{-1}$ & Spectrophotometry & Valderrama (1981) \\
\hline Total phosphorous (TP) & $<10.0$ & $\mu \mathrm{g} \cdot \mathrm{L}^{-1}$ & Spectrophotometry & Valderrama (1981) \\
\hline Nitrite $\left(\mathrm{N}-\mathrm{NO}_{3}^{-}\right)$ & $<8.0$ & $\mu g \cdot \mathrm{L}^{-1}$ & Spectrophotometry & Mackereth et al. (1978) \\
\hline Nitrate $\left(\mathrm{N}-\mathrm{NO}_{3}^{-}\right)$ & $<5.0$ & $\mu \mathrm{g} \cdot \mathrm{L}^{-1}$ & Spectrophotometry & Mackereth et al. (1978) \\
\hline Dissolved ammonium $\left(\mathrm{N}-\mathrm{NH}_{4}^{+}\right)$ & $<4.2$ & $\mu \mathrm{g} \cdot \mathrm{L}^{-1}$ & Spectrophotometry & Koroleff (1976) \\
\hline Orthophosphate (Pi) & $<10.0$ & $\mu g \cdot \mathrm{L}^{-1}$ & Spectrophotometry & Strickland \& Parsons (1960) \\
\hline Dissolved oxygen & & $\mathrm{mg} \cdot \mathrm{L}^{-1}$ & Titulometric & Golterman et al. (1978) \\
\hline $\begin{array}{l}\text { Chlorophyll } a, b, c \text {, } \\
\text { phaeopigments }\end{array}$ & & $\mu \mathrm{g} \cdot \mathrm{L}^{-1}$ & Spectrophotometry & $\begin{array}{l}\text { Jeffrey \& Humphrey (1975), } \\
\text { Lorenzen (1967), } \\
\text { Strickland \& Parsons (1960) }\end{array}$ \\
\hline
\end{tabular}

according Utermöhl. The number of chamber cells counted in each individual sample varied according to the species accumulation curve. To quantify cyanobacterial density in ind $\mathrm{ml}^{-1}$, an individual was considered a filament, a tricome, a colony, a cenobium or a cell (for unicellular individuals). To quantify cyanobacterial density in cell $\mathrm{ml}^{-1}$, the density based on ind $\mathrm{ml}^{-1}$ was multiplied by the mean number of cells per individual (calculated for 30 individual specimens of each species).

For cyanotoxin analysis, water samples were centrifuged $\left(5000 \mathrm{rpm}, 10 \mathrm{~min}\right.$ at $\left.4^{\circ} \mathrm{C}\right)$ and the resulting pellet stored at $-20^{\circ} \mathrm{C}$. Microcystin determination was carried out after sample cleanup, using solid phase extraction (SPE). Briefly, $100 \mathrm{mg}$ of the pellet were re-suspended in $10 \mathrm{~mL}$ of water, vortexed for $15 \mathrm{~s}$ and subjected to an ultrasonic probe for $1 \mathrm{~min}$ in an ice bath. After centrifugation $\left(5,000 \mathrm{rpm}, 10 \mathrm{~min}\right.$ at $\left.4{ }^{\circ} \mathrm{C}\right)$, the supernatant was loaded into a $\mathrm{C} 18$ cartridge (SepPak, Waters) previously conditioned with $\mathrm{MeOH}$ ( $3 \mathrm{~mL}$ ) and $\mathrm{H}_{2} \mathrm{O}(3 \mathrm{~mL})$. After the sequential washing with water $(3 \mathrm{~mL})$ and $\mathrm{MeOH} / \mathrm{H}_{2} \mathrm{O} 30 \%$ $(3 \mathrm{~mL})$, toxins were eluted with $\mathrm{MeOH}(3 \mathrm{~mL})$. The eluate was dried in a gentle stream of nitrogen and reconstituted in $200 \mu \mathrm{L}$ of $\mathrm{MeOH}$ for
LC-MSn Ion Trap analysis. The method proposed by Hiller et al., 2007 was employed for saxitoxin, anatoxin-a and cilindrospermopsin analyses. Briefly, $100 \mathrm{mg}$ of the pellet were re-suspended in $1 \mathrm{~mL} \mathrm{MeOH}$ :Acetic acid $0.1 \%(1: 1)$, subjected to an ultrasonic bath for $30 \mathrm{~min}$ and centrifuged at $5000 \mathrm{rpm}$ for $10 \mathrm{~min}$. The resulting supernatant was filtered and analyzed.

\section{RESULTS}

\section{Physical, chemical, and biological variables of the water}

The physical, chemical, and biological variables of the water are shown in Table 2. The water temperature was higher in February (summer) than in July (winter), $25.2^{\circ} \mathrm{C}$ and $19.5^{\circ} \mathrm{C}$, respectively. The water transparency was low in both periods. Electrical conductivity, $\mathrm{pH}$, and dissolved oxygen were $145.1 \mu \mathrm{S} \mathrm{cm}^{-1}, 7.8$ and $7.4 \mathrm{mg} \mathrm{L}^{-1}$ in February, respectively, and $204.1 \mu \mathrm{S} \mathrm{cm}^{-1}, 7.6$ and $6.2 \mathrm{mg} \mathrm{L}^{-1}$ in July, respectively. Total nitrogen concentrations were high in both periods, measuring $473.6 \mu \mathrm{g} \mathrm{L}^{-1}$ in February and 
Table 2. Values for the physical, chemical, and biological variables of the water in the Taquacetuba branch of the Billings Reservoir (São Paulo, Brazil) in February and July, 2007. Valores de las variables físicas, químicas, y biológicas del agua en la rama de Taquacetuba del Embalse de Billings (Sã o Paulo, Brasil) en febrero y julio de 2007.

\begin{tabular}{|c|c|c|}
\hline Variables & February & July \\
\hline Water temperature $\left({ }^{\circ} \mathrm{C}\right)$ & 25.2 & 19.5 \\
\hline Secchi disc (m) & 1.1 & 0.95 \\
\hline Electrical conductivity $\left(\mu \mathrm{S} \mathrm{cm}^{-1}\right)$ & 145.1 & 204.1 \\
\hline $\mathrm{pH}$ & 7.8 & 7.6 \\
\hline Dissolved oxygen $\left(\mathrm{mg} \mathrm{L}^{-1}\right)$ & 7.4 & 6.2 \\
\hline Total solids (mg L ${ }^{-1}$ ) & 114.0 & 339.5 \\
\hline Suspended particulate matter $\left(\mathrm{mg} \mathrm{L}^{-1}\right)$ & 8.8 & 164.0 \\
\hline Suspended particulate organic matter $(\%)$ & 88.7 & 95.1 \\
\hline Suspended particulate inorganic matter (\%) & 11.2 & 4.9 \\
\hline Total nitrogen $\left(\mu \mathrm{g} \mathrm{L}^{-1}\right)$ & 473.6 & 431.6 \\
\hline Nitrate $\left(\mu \mathrm{g} \mathrm{L}^{-1}\right)$ & 336.8 & 288.9 \\
\hline Nitrite $\left(\mu \mathrm{g} \mathrm{L}^{-1}\right)$ & 25.7 & 8.1 \\
\hline Ammonium $\left(\mu \mathrm{g} \mathrm{L}^{-1}\right)$ & 20.1 & - \\
\hline Total phosphorous $\left(\mu \mathrm{g} \mathrm{L}^{-1}\right)$ & 54.6 & 402.2 \\
\hline $\mathrm{N}: \mathrm{P}$ ratios & $19: 1$ & $2: 1$ \\
\hline Inorganic phosphorous $\left(\mu \mathrm{g} \mathrm{L}^{-1}\right)$ & - & 11.7 \\
\hline Chlorophyll $a\left(\mu \mathrm{g} \mathrm{L}^{-1}\right)$ & 33.2 & 867.0 \\
\hline Chlorophyll $b\left(\mu \mathrm{g} \mathrm{L}^{-1}\right)$ & 5.9 & 586.4 \\
\hline Chlorophyll $c\left(\mu \mathrm{g} \mathrm{L}^{-1}\right)$ & 0.3 & 29.9 \\
\hline Phaeophytin ( $\left.\mu \mathrm{g} \mathrm{L}^{-1}\right)$ & 12.0 & 310.0 \\
\hline
\end{tabular}

—: below the detection limit of the method

431.6 $\mu \mathrm{g} \mathrm{L}^{-1}$ in July. Among dissolved nitrogen forms, nitrate levels were higher than nitrite and ammonium in both periods. Total phosphorous was considerably higher in July $\left(402.2 \mu \mathrm{g} \mathrm{L}^{-1}\right)$ compared to February $\left(54.6 \mu \mathrm{g} \mathrm{L}^{-1}\right)$. In February, inorganic phosphate was below the analytic method limit $\left(<10 \mu \mathrm{g} \mathrm{L}^{-1}\right)$, while levels in July were found to be $11.7 \mu \mathrm{g} \mathrm{L}^{-1}$. Values of total solids, suspended particulate matter, and its organic fraction were much higher in July compared to those in February. Algae biomass, represented by concentrations of chlorophyll $a, b$, and $c$ and phaeophytin and the density of cyanobacteria also followed this same pattern of higher values in July and lower values in February. This pattern was due to an increased cyanobacterial bloom in July.

\section{Trophic state index}

According to the Trophic State Index (TSI) for chlorophyll, the waters of the Taquacetuba branch were classified as eutrophic in both periods (February with TSI $=63$ and July with TSI $=72$ ), whereas according to the TSI for total phosphorous, they were classified as eutrophic in February $(\mathrm{TSI}=57)$ and hypereutrophic $(\mathrm{TSI}=83)$ in July.

\section{Cyanobacteria composition and density}

A total of 13 taxa of cyanobacteria were identified, 8 in February and 10 in July (Table 3). Higher densities of cyanobacteria were found in July (2 914035.0 cel $\mathrm{mL}^{-1}$ ) compared to Fe- 
Table 3. Cyanobacteria taxa and densities in February and July, 2007, in the Taquacetuba branch of the Billings Reservoir (São Paulo, Brazil). Taxa de cianobacterias y densidades en febrero y julio de 2007, en la rama de Taquacetuba del Embalse de Billings (São Paulo, Brasil).

\begin{tabular}{lcc}
\hline & \multicolumn{2}{c}{ Density $($ cel mL) } \\
\cline { 2 - 3 } Cyanobacteria taxa & February & July \\
\hline Anabaena sp. & 0 & 1328 \\
\hline A. spiroides & 0 & 416511 \\
Aphanocapsa sp. & 6240 & 1287 \\
Cylindrospermopsis philippinensis & 352661 & 0 \\
C. raciborskii & 12849 & 0 \\
Merismopedia tenuissima & 14053 & 68840 \\
Microcystis aeruginosa & 0 & 1866725 \\
M. panniformis & 21397 & 0 \\
Microcrocis sp. & 23391 & 147665 \\
Planktothrix agardhii & 7804 & 3361 \\
Pseudanabaena sp. & 9004 & 29508 \\
P. galeata & 0 & 369729 \\
Woronichinia naegeliana & 447399 & 2914035 \\
Total & &
\end{tabular}

bruary (447 399 cel $\mathrm{mL}^{-1}$ ). In February, the taxa with higher densities were Cylindrospermopsis raciborskii $\left(352661 \mathrm{cel} \mathrm{mL}^{-1}\right)$, Plank-

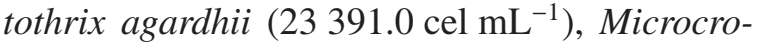
cis sp (21 $\left.397 \mathrm{cel} \mathrm{mL}^{-1}\right)$, and Microcystis aeruginosa (14 $\left.053 \mathrm{cel} \mathrm{mL}^{-1}\right)$. In July, a high density of Microcystis panniformis was found (1 $\left.866725 \mathrm{cel} \mathrm{mL}^{-1}\right)$, followed by Anabaena spiroides (416 511 cel $\mathrm{mL}^{-1}$ ), Woronichinia naegeliana (369 $\left.729 \mathrm{cel} \mathrm{mL}^{-1}\right)$, Planktothrix agardhii (147 $\left.665 \mathrm{cel} \mathrm{mL}^{-1}\right)$, and Microcystis aeruginosa $\left(68840\right.$ cel $\left.\mathrm{mL}^{-1}\right)$ (Table 4).

\section{Cyanotoxin analyses}

Microcystin analysis showed the presence of three different variants in both sampling periods, MC-RR, MC-LR and MC-YR, in different concentrations (Table 4). In February, three different microcystin variants were found (MC-RR, MCLR and MC-YR) in concentrations ranging from 0.26-0.47 $\mu \mathrm{g} \mathrm{L}^{-1}$ (7.83-14.15 ng MC/ $\mu \mathrm{g}$ Chl $a$ ).
Table 4. Results of the microcystin analysis in February and July, 2007, in the Taquacetuba branch of the Billings Reservoir (São Paulo, Brazil). Resultados de análisis microcystin en febrero y julio de 2007, en la rama de Taquacetuba del Embalse de Billings (São Paulo, Brasil).

\begin{tabular}{|c|c|c|c|c|c|c|}
\hline & \multicolumn{3}{|c|}{$\mu \mathrm{gMC}^{-1}$} & \multicolumn{3}{|c|}{ ngMC $\mu$ gChl $a^{-1}$} \\
\hline & MC-RR & MC-LR & MC-YR & MC-RR & MC-LR & MC-YR \\
\hline February & 0.47 & 0.28 & 0.26 & 14.15 & 8.43 & 7.83 \\
\hline July & 0.55 & 0.57 & 0.29 & 0.64 & 0.66 & 0.33 \\
\hline
\end{tabular}

In July, the same microcystin variants were found, ranging in concentration from $0.29-0.57 \mu \mathrm{g} \mathrm{L}^{-1}$

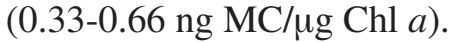

Saxitoxin was detected only in February. Neither cylindrospermopsin nor anatoxin-a were detected in either of the samples.

\section{DISCUSSION}

Analyses of the physical, chemical, and biological variables of the water from the Taquacetuba branch in February (summer) and July (winter) revealed a marked seasonality.

In this study, the cyanobacterial bloom was more intense in July (winter) than in February (summer), reflecting major electrical conductivity, higher levels of total solids, suspended particulate matter, total phosphorus, chlorophyll $a, b, c$, phaeophytin, and cyanobacteria density. The dominance of cyanobacteria in nutrient-rich environments has been associated with a variety of factors. Environmental factors, such as low turbulence (Reynolds, 1987), low light (Smith, 1986), low ratio of euphotic zone to mixing zone (Jensen et al., 1994), high temperature (Shapiro, 1990), low $\mathrm{CO}_{2} /$ high $\mathrm{pH}$ (Caraco \& Miller, 1998), high total-P (Falconer, 2005; Watson et al., 1997), low total-N (Smith, 1983), and phosphorus storage strategy (Pettersson et al., 1993), have all been refereed to as being able to promote or allow cyanobacterial dominance.

According to Tilman's (1982) resource-ratio hypothesis, cyanobacterial dominance had also been attributed to low N:P ratios (Bulgakov \& Levich, 1999; Hoyos et al., 2004; Smith, 1983; Tilman et al., 1986). Indeed, in this study, we observed higher cianobacterial density in July, 
when the N:P ratios were very low. According to Falconer (2005), phosphorus availability is a major determinant of growth rate for cyanobacteria and has a substantial effect on toxin production. However, this pattern was not reflected in a higher cyanotoxin production in July. It may suggest that environmental factors (water temperature and light, for instance) in this period didn't favor the production of toxins, despite of the more intense bloom. The irregularity of the toxicity of cyanobacteria is not yet defined (Carmichael, 1992). Environmental factors such as light, temperature, and nutrients have a large influence on the production of cyanotoxins.

Sant'Anna et al. (2007) yield a study of cyanobacteria biodiversity and distribution in reservoirs of the upper Tietê River, in which the Billings Reservoir is located. The authors concluded that within the results of the physical and chemical conditions of the reservoirs, Billings Reservoir proved to be the most favorable environment for the development of these organisms.

The abundance and persistent predominance of cyanobacteria species observed in this study are probably linked to the high levels of eutrophication in the Taquacetuba branch, as indicated by the TSI (eutrophic-hypereutrophic), which reflected elevated algae biomass, low water transparency, very high concentrations of nutrients (total nitrogen and phosphorous) and, consequently, seriously compromised the use of the water for the public's water supply, as well as other uses.

Sant'Anna \& Azevedo (2000) and Komarek et al. (2002) reported cyanobacteria blooms in Brazil resulting from the increase in nutrients. According to Tucci \& Sant'Anna (2003), Cylindrospermopsis raciboskii blooms have been increasingly frequent in Brazilian reservoirs because of its high competitiveness in eutrophic tropical environments. In an eutrophic reservoir in Rio Grande do Norte State with high concentrations of inorganic matter, reduced transparency, anoxic hypolimnion, and high electrical conductivity, Chellappa \& Costa (2003) detected a large presence of cyanobacteria (Cylindrospermopsis raciborskii, Raphidiopsisi curvata, Microcystis aeruginosa, and Oscillatoria sp) in the dry season. Azevedo \& Vasconcelos (2006) detected toxic strains of cyanobacteria in bodies of water including reservoirs used for public water supply, artificial lakes, salt lakes, and rivers in the states of São Paulo, Rio de Janeiro, Minas Gerais, Paraná, Bahia, and Pernambuco, and in the Federal District. At these locales, approximately $82 \%$ of the strains isolated were found to be toxic, with $9.7 \%$ being neurotoxic and the rest hepatotoxic. Minillo et al. (2000) detected the presence of microcystins in an estuary in Rio Grande do Sul, Lagoa dos Patos, in the summer and fall months. Carvalho et al. (2007) detected greater biodiversity of potentially toxic cyanobacteria in the Billings Reservoir compared to the Guarapiranga Reservoir. They found $67 \%$ of the species collected in the Billings Reservoir to be potentially toxic and $50 \%$ in the Guarapiranga Reservoir. Analyses of microcystin confirmed these results, as microcystin was detected in the Billings Reservoir throughout the entire study period, whereas in the Guarapiranga Reservoir, microcystin was only detected in the samples containing Microcystis.

Brazilian studies have shown that the most common toxic cyanobacteria blooms are those that produces microcystins and saxitoxin, the same toxins found in the Taquacetuba branch in this study (Molica \& Azevedo, 2009).

Microcystins are produced by several cyanobacterial genera, such as Microcystis, Anabaena, Planktothrix (Oscillatoria), Nostoc, Hapalosiphon, and Anabaenopsis while saxitoxins are produced by Anabaena, Aphanizomenon, Lyngbya, and Cylindrospermopsis (Chorus \& Bartram, 1999). A Cylindrospermopsis raciborskii bloom in February, associated with the presence of saxitoxin, suggests the production of this toxin by this species, as already demonstrated in other freshwater environments in Brazil (Lagos et al., 1999; Molica et al., 2002). However, further research is necessary in order to confirm the origin of this toxin and to quantify it. The presence of microcystin in both periods was probably due to high densitites of Microcystis aeruginosa and Planktothrix agardhii in February and Microcystis panniformis and also Planktothrix agardhii in July. A more intense bloom with higher cyanobacterial densities in July was related to higher microcystins concentrations in this period. 
In an eutrophic Brazilian reservoir (Armando Ribeiro Gonçalves Reservoir, Rio Grande do Norte State), Costa et al. (2006) detected microcystins concentrations as high as $8.8 \mu \mathrm{g} \mathrm{L}^{-1}$. Andrade (2005) found lower concentrations of microcystins $\left(3.5 \mu \mathrm{g} \mathrm{L}^{-1}\right)$ at the Guarapiranga Reservoir (São Paulo State) and Yunes et al. (2003) found much lower concentrations of this toxin $\left(0.03 \mu \mathrm{g} \mathrm{L}^{-1}\right)$ in the Duro reservoir (Rio Grande do Sul State) and $0.01 \mu \mathrm{g} \mathrm{L}^{-1}$ of saxitoxin in the Taiaçupeba reservoir (São Paulo State). Most Brazilian reservoirs are in exceptionally good conditions for the development of toxic cyanbacteria: light availability, high temperatures, water column stability, high water retention time and high nutrient concentrations ( $\mathrm{N}$ and $\mathrm{P}$ ) (Fernandes et al., 2009).

Cyanobacteria density during this study exceeded the levels for drinking water $\left(>2 \cdot 10^{3}\right.$ cells $\left.\mathrm{mL}^{-1}\right)$ recommended by the WHO-World Health Organization (Chorus \& Bartram, 1999), and also the limit set by the Brazilian Health Ministry $\left(20 \cdot 10^{3}\right.$ cells $\left.\mathrm{mL}^{-1}\right)$ (Brasil, 2004). Due to the high toxicity of microcystins, WHO established the value $1.0 \mu \mathrm{g} \mathrm{L}^{-1}$ as the maximum microcystin-LR concentration in drinking water (Chorus \& Bartram, 1999).

Although water from Taquacetuba is not directly used for water supply, microcystin-LR level at $0.57 \mu \mathrm{g} \mathrm{L}^{-1}$ in July is a cause of concern because of the difficult removal of this toxin with conventional water treatment process (Lambert et al., 1996). Additionally, raw water containing 1.01 and $1.41 \mu \mathrm{g} \mathrm{L}^{-1}$ of total microcystins in February and July, respectively, mean exposures to doses near the guideline value for the local population that uses the reservoir as a recreation site. This situation should be considered as a serious public health threat, since prolonged exposure to microcystins can lead to a higher incidence of liver cancer (Azevedo, 1998; Chorus \& Bartram, 1999). Exposure of the local population through cyanotoxin accumulation in fish musculature must also be considered (Magalhães et al., 2001).

The findings of the present study are of great concern. The water in the Taquacetuba branch is not treated nor managed, and it is channeled into the Guarapiranga Reservoir. Thus, it is recom- mended that monitoring be intensified, and more effective measures be taken by the agencies responsible for the elimination of the causes of the eutrophication process and the consequent development of cyanobacteria and its toxins.

\section{ACKNOWLEDGEMENTS}

Funded by: CNPQ (NUM. 475166/2006-6)FAPESP (NUM. 0213376-4). FUNDUNESP: (NUM. 00675/08-DFP).

\section{REFERENCES}

ANDRADE, A. A. S. 2005. Análise da eficiência da várzea do Ribeirão Parelheiros na melhoria de qualidade das águas que afluem a represa do Guarapiranga, São Paulo. Tesis Doctoral, EESC. University of São Paulo. 91 pp.

AZEVEDO, S. M. F. O., W. R. EVANS, W. W. CARMICHAEL \& M. NAMIKOSHI. 1994. First report of microcystins from a Brazilian isolate of the Cyanobacterium Microcystis aeruginosa. Journal of Applied Phycology, 6: 261-5.

AZEVEDO, S. M. F. O. 1998. Toxinas de cianobactérias: Causas e consequiências para a saúde pública. Medicina on line, 3: 1-19.

AZEVEDO, S. M. F. O. \& V.VASCONCELOS. 2006. Toxinas de cianobactérias: causas e consequiências para a saúde pública. In: Ecotoxicologia aquática. Príncipios e Aplicações. P. A. Zagatto \& E. Bertoletti (Eds.): 433-452. Ed. Rima.

BEYRUTH, Z. \& H. A. D. S. L. PEREIRA. 2002. O isolamento do Rio Grande da represa Billings, São Paulo: Efeitos sobre o fitoplâncton durante um ciclo hidrológico completo. B. Inst. Pesca, 28: 111123.

BRASIL 2004. Portaria 518, de 25 de março de 2004. Diário Oficial da República Federativa do Brasil, Poder Executivo. Brasília (DF).

BULGAKOV, N. G. \& A. P. LEVICH. 1999. The nitrogen:phosphorus ratio as a factor regulating phytoplankton community structure. Arch. Hydrobiol., 146: 3-22.

CALIJURI, M. C. C., M. S. A. ALVES \& A. C. A. DOS SANTOS. 2006. Cianobactérias e cianotoxinas em águas continentais. 109 pp. Ed. Rima. 
CARACO, N. \& R. MILLER. 1998. Factors influencing the abundance of blue-green algae in Florida lakes. Can. J. Fish. Aquat. Sci., 46: 1232-1237.

CARMICHAEL, W. W. 1992. Cyanobacteria secondary metabolites-The Cyanotoxins. J. Appl. Bact., 72: 445-459.

CARVALHO, L. R., C. SANT'ANNA, M. C. P. GELMEGO \& M. T. P. AZEVEDO. 2007. Cyanobacterial occurrence and detection of microcystin by planar chromatography in surface water of Billings and Guarapiranga reservoir. Revta. Brasil. Bot., 30(1): 141-148.

CHELLAPPA, N. T. \& M. A. M. COSTA. 2003. Dominant and co-existing species of cyanobacteria from a eutrophicated reservoir of Rio Grande do Norte State, Brazil. Acta Oecologica, 24: S3-S10.

CHORUS, I. \& J. BARTRAM. 1999. Toxic cyanobacteria in water-a guide to their public health consequences, monitoring and management. WHO, Spon Press, London.

COSTA, I. A. S., S. M. F. O. AZEVEDO, P. A. C. SENNA, R. R. BERNARDO, S. M. COSTA \& N. T. CHELLAPPA. 2006. Occurrence of toxinproducing cyanobacteria blooms in a Brazilian semiarid reservoir. Braz. J. Biol., 66: 211-219.

FALCONER, I. R. 2005. Cyanobacterial toxins of drinking water supplies-cylindrospermopsins and microcystins. CRC Press, U.S. 299 pp.

FERNANDES, V. D. O., B. CAVATI, L. B. D. OLIVEIRA \& B. D. Â. D. SOUZA. 2009. Ecologia de cianobactérias: Fatores promotores e consequências das florações. Oecol. Bras., 13: 247-258.

GOLTERMAN, H. L., R. S. CLYMO, \& M. A. M. OHNSTAD. 1978. Methods for physical and chemical analysis of freshwaters: Oxford. Blackwell Scientific Publications, I.B.P. Handbook. 1978.v. 8. 213 pp.

HILLER, S., B. KROCK, A. CEMBELLA \& B. LUCKAS. 2007. Rapid detection of cyanobacterial toxins in precursor ion mode by liquid chromatography tandem mass spectrometry. Journal of Mass Spectrometry, 42: 1238-1250.

HOYOS, C., A. I. NEGRO \& J. J. ALDASORO. 2004. Cyanobacteria distribution and abundance in the Spanish water reservoirs during thermal stratification. Limnetica, 23: 119-132.

JEFFREY, S. W. \& G. F, HUMPHREY. 1975. New spectrophotometric equations for determining chlorophylls a, b, c1 e c2 in higher plants, algae, and natural phytoplankton. Physiol. Pflanzen (BPP), 167: 191-194.
JENSEN, J. P., E. JEPPESEN, K. OLRIK \& P. KRISTENSEN. 1994. Impact of nutrients and physical factors on the shift from cyanobacterial to chlorophyte dominance in shallow Danish lakes. Can. J. Fish. Aquat. Sci., 51: 1692-1699.

KOMAREK, J., J. KORMAKOVA-LEGNEROVA, C. L. SANT'ANNA, M. C. T. AZEVEDO \& P. S. SENNA 2002. Two commom Microcystis species (Chroococcales, Cyanobacteria) from tropical America, including M. Panniformics sp nov. Cryptogamie. Algologie, 23(2): 159-177.

KOROLEFF, F. 1976. Determination of nutrients. In: Methods of seawater analysis. K. GRASSHOFF (ed.): 117-181. Verlag Chemie Weinhein,

LAGOS, N., H. ONODERA, P. A. ZAGATTO, D. ANDRINOLO, S. M. F. Q. AZEVEDO \& Y. OSHIMA. 1999. The first evidence of paralytic shellfish toxins in the freshwater cyanobacterium $C y$ lindrospermopsis raciborskii, isolated from Brazil. Toxicon, 37: 1359-1373.

LAMBERT, T. W., HOLMES, C. F. B. \& HRUDEY, S. E. 1996. Adsorption of microcystin-LR by activated carbon and removal in full scale water treatment. Water Res., 30: 1411-1422.

LORENZEN, C. J. 1967. Determination of chlorophyll and pheo-pigments: spectrophotometric equations. Limnol. Oceanogr., 12: 343-346.

MAGALHÃES, V. F., R. M. SOARES \& S. M. F. O. AZEVEDO. 2001. Microcystin contamination in fish from the Jacarepaguá lagoon (Rio de Janeiro, Brazil): Ecological implication and human health risk. Toxicon, 39: 1077-1085.

MACKERETH, F. J. H., J. HERON. \& J. F. TALLING. 1978. Water analysis: some revised methods for limnologists. Freshwater Biological Association. Scientific Association. n. 36. Titus Wilson \& Son Ltda. Kendall. 117 pp.

MINILLO, A., A. H. F. FERREIRA, G. T. YOGUI \& J. S. YUNES. 2000. Concentrações de microcistinas e toxicidade na formas coloniais de $\mathrm{Mi}$ crocystis aeruginosa de florações no estuário da lagoa dos Patos, RS. In: Ecotoxicologia. Perspectivas para o Século XXI. E.L.G. Espíndola, C.M.R Botta-Paschoal, O. Rocha, M.B.C. Bohrer, A.L. Oliveira-Neto (eds.): 521-536. São Carlos, Ed. Rima.

MOLICA, R. \& S. AZEVEDO. 2009. Ecofisiologia de cianobactérias produtoras de cianotoxinas. $O e$ col. Bras., 13: 229-246.

MOLICA, R., H. ONODERA, C. GARCIA, M. RIVAS, D. ANDRINOLO, S. NASCIMENTO, H. 
MEGURO, Y. OSHIMA, S. AZEVEDO \& N. LAGOS. 2002. Toxins in the freshwater cyanobacterium Cylindrospermopsis raciborskii (Cyanophyceae) isolated from Tabocas reservoir in Caruaru, Brazil, including demonstration of a new saxitoxin analogue. Phycologia, 41: 606-611.

PETTERSSON, K., E. HERLITZ \& V. ISTVÁNOVICS. 1993. The role of Gloeothrichia echinulata in transfer of phosphorus from sediments to water in lake Erken. Hydrobiologia, 253: 123-129.

REYNOLDS, C. S. 1987. Cyanobacterial waterblooms. In: Advances in botanical research. Callow, J. (ed.): 67-143. Academic Press. London.

SANT'ANNA, C. L., M. T. D. AZEVEDO. 2000. Contribution to the knowledge of potentially toxic Cyanobactera from Brazil. Nova Hedwigia, 71: 359-385.

SANT'ANNA, C., S. M. SILVA, M. C. CARVALHO, M. C. P. GELMEGO \& M. T. P. AZEVDO. 2007. Planktic cyanobacteria from upper Tiête basin reservoir, SP, Brasil. Revta. Brasil. Bot., 30: 1-17.

SHAPIRO, J. 1990. Currents beliefs regarding dominance by blue-greens: The case for the importance of $\mathrm{CO}_{2}$ and $\mathrm{pH}$. Vehr. Int. Verein. Theor. Angew. Limnol., 24: 38-54.

SMITH, V. H. 1983. Low nitrogen to phosphorus ratios favour dominance by blue-green algae in lake phytoplankton. Science, 221: 669-671.

SMITH, V. H. 1986. Light and nutrient effects on the relative biomass of blue-green algae in lake phytoplankton. Can. J. Fish. Aquat. Sci., 43: 48-153.

SOUZA, R. C. R., M. C. CARVALHO \& A. C. TRUZZI. 1998. Cylindrospermopsis raciborskii (Wolosz.) Seenaya and a contribution to the knowledge of Rio Pequeno arm, Billings reservoir, Brazil. Environmental Toxicology and Water Quality, 13: $73-81$

STRICKLAND, J. D. \& T. R. PARSONS. 1960. A manual of seawater analysis. Bull. Fish. Res. Board. Can., 125: 1-185.

TILMAN, D., R. KIESLING, R. STERNER, S. S. KILHAM \& F. A. JOHNSON. 1986. Green, blue green and diatom algae: Taxonomic differences in competitive ability for phosphorus, silicon and nitrogen. Arch. Hydrobiol., 106: 473-485.

TUCCI, A. \& C. L. SANT'ANNA. 2003. Cylindrospermopsis raciborskii (Woloszynska) Seenayya \& Subba Raju (Cyanobacteria): Variação semanal e relações com fatores ambientais em um reservatório eutrófico, São Paulo, SP, Brasil. Revista Brasil. Bot. 26: 97-112.

TOLEDO Jr., A. P. DE, N. TALARICO, S. J. CHINEZ \& E. G. AGUDO. 1993. Aplicação de modelos simplificados para a avaliação de processo de eutrofização em lagos e reservatórios tropicais. Anais $12^{0}$ Congresso Brasileiro de Engenharia Sanitária e Ambiental. CETESB: 1-34.

TUCCI, A. \& C. L. SANT'ANNA. 2003. Cylindrospermopsis raciborskii (Woloszynska) Seenayya \& Subba Raju (Cyanobacteria): variação semanal e relações com fatores ambientais em um reservatório eutrófico, São Paulo, SP, Brasil. Revta. Brasil. Bot., 26(1): 97-112.

VASCONCELOS, V. 2006. Eutrophication, toxic cyanobacteria and cyanotoxins: When ecosystems cry for help. Limnetica, 25: 425-432.

VALDERRAMA, J. C. 1981. The simultaneous analysis of total nitrogen and phosphorus in natural waters. Mar. Chem., 10: 109-122.

WATSON, S. B., E. MCCAULEY \& J. A. DOWNING. 1997. Patterns in phytoplankton taxonomic composition across temperate lakes of differing nutrient status. Limnol. Oceanogr., 42: 487-495.

WHATELY, M. \& P. CUNHA. 2006. Seminário Guarapiranga - Proposição de ações prioritárias para garantir água de boa qualidade para abastecimento público. Instituto Socioambiental. São Paulo, $171 \mathrm{pp}$.

WETZEL, R. G. \& G.E. LIKENS. 1991. Limnological Analyses. $2^{\text {ond }}$ ed. Springer-Verlag. 391 pp.

YUNES, J. S., N. T. CUNHA, L. P. BARROS, L. A. O. PROENÇA \& J. M. MONSERRAT. 2003. Cyanobacterial Neurotoxins from Southern Brazil. Comments on Toxicology, 9: 103-115. 